\title{
Geology of Arctic Margins: Proceedings of ICAM VII 2015
}

\author{
Morten Smelror ${ }^{1}$ \\ ${ }^{1}$ Geological Survey of Norway, P.O. Box 6315 Sluppen, N-7491 Trondheim, Norway. \\ E-mail: Morten.Smelror@ngu.no
}

The present NJG issue consists of six contributions on the geology of the Arctic, including papers presented at the 7th International Conference on Arctic Margins (ICAM) in Trondheim, June 2015. Since its initiation 25 years ago, ICAM has become a well established forum for Earth scientists studying the Arctic. The papers in the present issue cover Cretaceous magmatism in Canada, biostratigraphy of the Upper Jurassic, Cretaceous and Paleocene strata on Svalbard, and a new model for Late Weischselian time-transgressive glacial maxima positions of the last Scandinavian Ice Sheet.

Keywords: Arctic, Canada, Scandinavia, magmatism, LIP, biostratigraphy, ice-sheet, Jurassic, Cretaceous, Paleocene, Quaternary, ICAM

Received 29. August 2016 / Accepted 30. August 2016 / Published online 26. September 2016

\section{Introduction}

To meet the challenges of exploring the remaining frontiers of the Arctic we need good international scientific cooperation and communication. The International Conference on Arctic Margins (ICAM) is a forum for Earth scientists who study the Arctic. ICAM was founded by the U.S. Department of the Interior Bureau of Ocean Energy Management in 1991 with the underlying themes of Arctic understanding and international cooperation in Arctic research. Since its very beginning ICAM has proved a successful arena for improving our geo-scientific knowledge of the Arctic and fostering cooperation and collaboration among Arctic researchers. ICAM is organised, hosted and conducted by scientists for scientists, which makes it a unique forum.

In June 2015 the 7th International Conference on Arctic Margins (ICAM-VII 2015) was arranged in Trondheim, Norway. Prior to the conference in Trondheim, meetings have been held in Anchorage, Magadan, Celle, Dartmouth, Tromsø and Fairbanks since the inception of ICAM 25 years ago (Stone et al., 2014).
ICAM VII 2015 in Trondheim included 100 presentations (56 oral, 44 posters) covering the following topics: New data on seafloor geology and deep structure of the Arctic Basin and adjacent areas; their implementation in international projects, with a subsession on planned field activities; Circum-Arctic onshore-offshore structural relations; Stratigraphy, paleoenvironments and geological history of the Arctic basin and adjacent areas; Arctic Large Igneous Provinces and their geodynamic significance; Plate reconstructions and lithosphere evolution of the Arctic region; Glacial events and their geological consequences (with a subsession on the origin of bottom sediments); and Arctic Gas Hydrates. Abstracts of the presentations are available at http://www.ngu.no/upload/ Publikasjoner/Rapporter/2015/ 2015_032.pdf (Smelror, 2015).

The present NJG issue consists of papers presented at the $7^{\text {th }}$ International Conference on Arctic Margins (ICAM) in Trondheim, June 2015, and related papers on Arctic geology. The contributions cover Cretaceous magmatism in Canada, biostratigraphy of the Upper Jurassic, Cretaceous and Paleocene strata on Svalbard, and a new 
model for Late Weischselian time-transgressive glacial maxima positions of the last Scandinavian Ice Sheet.

\section{Arctic Cretaceous magmatism}

Magmatic activity linked to continental rifting, subduction zones and ocean floor formation in the High Arctic is documented for at least the past 440 million years, with the most widespread magnetic event taken place around Mid Cretaceous times.

Estrada et al. (2016) have used combined results of aeromagnetic surveys, geological fieldwork, geochronological, geochemical and $\mathrm{Sr}-\mathrm{Nd}$ isotope analysis from the Yelverton Bay area, north coast of Ellesmere Island, to study the tectonic history of this part of the Canadian Polar margin. Here, a characteristic magnetic high overlapping the shelf and coastal area is interpreted to be a part of the Cretaceous High Arctic Large Igneous Province (HALIP).

Estrada et al. (2016) find that the basement, consisting of metamorphic rocks of the Pearya Terrane, was strongly affected by HALIP-related magmatism that is responsible for the characteristic positive magnetic anomaly patterns. They document that a broad magnetic high which can be traced to the Alpha Ridge and covers the shelf and coastal areas of Yelverton Bay, is caused by a voluminous intrusion into the continental crust at a depth of $c$. 6-15 $\mathrm{km}$. A chain of small positive magnetic anomalies crosses Wootton Peninsula from SW to NE and then curves into a NNE-SSW trend. It follows the coastline onshore and offshore and superimposes the southern and eastern margins of the broad magnetic high. Estrada et al. (2016) document that, on land, the anomaly chain covers faultbounded outcrops of the Wootton Intrusive Complex (WIC) and the Hansen Point Volcanic Complex (HPVC), indicating that the entire anomaly chain is associated with a volcanogenic sequence.

Based on U-Pb zicon ages Estrada et al. (2016) have found that rhyodacite forming large parts of the HPVC east and west of Yelverton Bay extruded between $c .104$ and $97 \mathrm{Ma}$. They suggest that it originates from a tholeiitc suite and is probably genetically related to the deep intrusion. The HPVC together with the rhyodacite has an age range of $c$. 104-74 Ma and includes the mildly alkaline WIC (93-92 Ma). Estrada et al. (2016) further find that the northern coast of Ellesmere Island shows some characteristic features of a magma-rich rifted margin indicating an extensional evolution parallel to the North American margin between the openings of the Canada Basin and the Eurasian Basin.

Kingsbury et al. (2016) have studied trace element and $\mathrm{Sm}-\mathrm{Nd}$ isotopes in laves from the High Arctic LIP in
Canada and used these as evidence for the role of mantle heterogeneity and crustal assimilation. In Arctic Canada, magmatism is largely recorded as extensive Early Cretaceous lavas of the Isachsen Formation, Late Cretaceous continental flood basalts of the Strand Fiord Formation, and an extensive network of dykes and sills forming their plumbing systems.

Axel Heiberg Island near South Fiord contains a small, structurally complex portion of the overall network of HALIP tabular intrusions, from which samples from the South Fiord intrusions and Isachsen Formation basaltic lavas were analysed to better understand their petrogenesis. Specifically, Kinsgsbury et al. (2016) have applied trace-element ratios together with $\mathrm{Sm}-\mathrm{Nd}$ isotope systematics in order to identify processes that shaped the chemical evolution of the South Fiord intrusions and Isachsen Formation lavas, to identify mantle source chemistries and the role of crustal assimilation.

On the basis of their Sm-Nd isotopic results, Kingsbury et al. (2016) find that South Fiord intrusion magmas were derived from a homogeneous mantle source whereas a more heterogeneous source is invoked for the Isachsen Formation lavas. Furthermore, modelling with Th/La, $\mathrm{Nb} / \mathrm{U}, \mathrm{Ba} / \mathrm{Th}$ and $\mathrm{Ba} / \mathrm{Nb}$ suggests that South Fiord intrusive magmatism was contaminated by sedimentary rocks from the Sverdrup Basin.

Kingsbury et al. (2016) conclude that a trend towards high $\mathrm{Ba} / \mathrm{Th}$ in Isachsen Formation lavas, suggests a subducted sediment component derived from extinct subduction zones. They surmise that South Fiord intrusive rocks are geochemically distinct from the Isachsen Formation lavas, and further that the HALIP mantle plume head intersected and incorporated sediments from ancestral subduction zones to the present-day Aleutian and Alaska subduction zones to produce the Isachsen Formation flows. In contrast, the South Fiord intrusions (and correlated Strand Fiord magmatism) were generated from plume material that interacted with upper crustal sedimentary rocks.

\section{Late Jurassic - Paleocene stratigraphy on Svalbard}

The Svalbard Archipelago forms the subaerially exposed northwestern margin of the Barents Shelf. The archipelago represents an important window into the geology of the entire region, and has for decades been a key site for geological research workers from many countries. Several overviews of the geological history and stratigraphy of Svalbard have been published, including a monograph of Harland (1997), a Lithostratigraphic Lexicon published by Dallmann (1999), a synopsis by Worsley (2008) and a recent Geological Atlas edited by Dallmann (2015). The 
latter provides a comprehensive list of references to biostratigraphic studies carried out on the islands over the past century.

Dalseg et al. (2016a) analysed the Upper Jurassic-Lower Cretaceous sedimentary succession in the Isfjorden area (central Spitsbergen) for marine palynomorphs and palynofacies, and they defined two informal dinoflagellate cyst assemblage zones in the Slottsmøya Member of the Agardhfjellet Formation. The palynostratigraphic zones are established with reference to $\delta^{13} \mathrm{C}$ curves, and are correlated with Early Volgian to Late Ryazanian foraminiferal zones and ammonite zones from the same area. A Leiosphaeridia bloom at $45.62 \mathrm{~m}$ in the Janusfjellet profile is correlated with a comparable bloom recovered from several locations on the western Barents shelf. Dalseg et al. (2016a) further used palynofacies analysis to interpret relative sea-level changes and to constrain the sequence stratigraphy of the studied sections at Janusfjellet and Knorringfjellet.

In a second paper, Dalseg et al. (2016b) present the first detailed report of organic-walled microfossils and palynodebris in cold seep carbonate deposits from the Upper Jurassic-Lower Cretaceous Agardhfjellet Formation on Svalbard. To our knowledge this is the first published report on such Mesozoic cold hydrocarbon seep deposits. The organic-walled microfossils and palynodebris comprise ex situ fossil material in the seep deposits and consist of both specimens that originated during the time of deposition and a few fossils reworked from older strata. Due to early authigenic precipitation of carbonate, the palynomorphs from the Agardhfjellet Formation carbonate seep deposits in Central Spitsbergen, Svalbard, are better preserved than the palynological material in the shale deposits in the same formation. According to Dalseg et al. (2016b), the Non-metric Multidimensional Scaling (NMDS) of the dinoflagellate cyst assemblages in the studied succession shows an age-specific trend, rather than being environmentally controlled, while the NMDS of the palynofacies shows that the content of palynodebris in the samples is more environmental-specific than age-specific.

Paleogene formations on eastern Sørkapp Land contain common, reworked, Middle and Late Cretaceous, terrestrial and marine microfloras. Smelror \& Larssen (2016) argue that their observations question the Late Cretaceous age reported for the Firkanten Formation in the Øyrlandet Graben on western Sørkapp Land by Krutzsch (2001), as the pollen and spores reported from this graben may not be in situ. The palynostratigraphic data provided by Smelror \& Larssen (2016) suggest that the Firkanten and Basilika formations on Sørkapp Land were deposited in a relatively short time-period during the Early to Mid Thanetian. The youngest Cretaceous deposits documented from the Carolinefjellet Formation in eastern Sørkapp Land are of Late Albian age.

\section{Late Weischselian Scandinavian Ice Sheet}

The positions and causes of the glacial maxima positions of the Scandinavian Ice Sheet have been studied intensively for decades. Reconstructions of ice cover during the time spanning the Late Weichselian maximum carried out by Larsen et al. (2016) show a confluent Eurasian ice sheet with the Scandinavian Ice Sheet positioned between the Svalbard-Barents-Kara and the British-Irish ice sheets.

It has long been suspected among glacial geologists that the maximum ice-marginal position was asynchronous, but only recently has it been possible to explore this in some detail. Dates pertaining to the ice margin of the Scandinavian Ice Sheet reveal an old (29-25 ka) maximum position along its western flank, whereas a younger (18-16 ka) maximum position has been delineated along its eastern flank.

According to the model of Larsen et al. (2016), a timedistance diagram across the Scandinavian Ice sheet shows an oscillatory western ice front, as opposed to a steadily growing and decaying eastern ice margin. The largest age difference between maximum positions is as much as $10 \mathrm{ka}$ between different sectors of the Scandinavian Ice Sheet. Larsen et al. (2016) argue that older maximum positions of the western margin can be explained by its proximity to ice-growth centres, initial windward ice growth, efficient ice drainage in ice streams on the Norwegian continental shelf, and the continental shelf break being a barrier to further westward expansion.

Larsen et al. (2016) further find that younger maximum positions of the eastern margin can be explained by a very long distance between ice-growth centres and marginal positions, slow flow in a wide zone of cold-based to partly cold-based ice, and punctuated advances of lowgradient ice lobes into proglacial lakes along the extreme eastern perimeter of the ice sheet. Larsen at al. (2016) conclude that the influence of these lakes on the glacier dynamics of adjoining ice lobes prolonged the ice sheet advance by some 1 to $3 \mathrm{ka}$ compared with adjacent interlobate areas.

Acknowledgements. Thanks are due to the following scientists who helped us review the papers included in this NJG special Arctic issue: Christian Tegner, Anna Hughes, Adrian Hall, Kasia K. Sliwinska, Henning Dypvik, Henrik Nøhr-Hansen, William Helland-Hansen, Richard Ernst, Thomas Funck and anonymous reviewers. 


\section{References}

Dallmann, W.K. (ed.) 1999: Lithostratigraphic Lexicon of Svalbard. Norsk Polarinstitutt, Tromsø, $318 \mathrm{pp}$.

Dallmann, W.K. (ed.) 2015: Geoscience Atlas of Svalbard. Norwegian Polar Institute Report Series 148, Tromsø, Norway: Norwegian Polar Institute, 292 pp.

Dalseg, T.S., Nakrem, H.A. \& Smelror, M. 2016a: Dinoflagellate biostratigraphy, palynofacies, depositional environment and sequence stratigraphy of the Agardhfjellet Formation (Upper Jurassic-Lower Cretaceous) in central Spitsbergen (Arctic Norway). Norwegian Journal of Geology 96, 119-132. http://dx.doi.org/10.17850/njg962-04.

Dalseg, T.S., Nakrem, H.A. \& Smelror, M. 2016b: Organic-walled microfossils and palynodebris in cold seep carbonate deposits: The Upper Jurassic-Lower Cretaceous Agardhfjellet Formation on Svalbard (Arctic Norway). Norwegian Journal of Geology 96, 133144. http://dx.doi.org/10.17850/njg96-2-01.

Estrada, S., Damaske, D., Henjes-Kunst, F., Schreckenberger, B., Oakey, G.N., Piepjohn, K., Eckelmann, K. \& Linnemann, U. 2016: Multistage Cretaceous magmatism in the northern coastal region of Ellesmere Island and its relation to the formation of Alpha Ridge - evidence from aeromagnetic, geochemical and geochronological data. Norwegian Journal of Geology 96, 65-95. http://dx.doi. org/10.17850/njg96-2-03.

Harland, W.B. 1997: The geology of Svalbard. Geological Society of London, London, $521 \mathrm{pp}$.

Kingsbury, C.G., Ernst, R.E., Cousens, B.L. \& Williamson, M.-C. 2016: The High Arctic LIP in Canada: Trace element and Sm-Nd isotopic evidence for the role of mantle heterogeneity and crustal assimilation. Norwegian Journal of Geology 96, 97-118. http://dx.doi. org/10.17850/njg96-2-02.

Krutzsch, W. 2001: An Upper Cretaceous Microflora from Spitsbergen, Geologisches Jahrbuch B91, 693-713.

Larsen, E., Fredin, O., Lyså, A., Amantov, A., Fjeldskaar, W. \& Ottesen, D. 2016: Causes of time-transgressive glacial maxima positions of the last Scandinavian Ice Sheet. Norwegian Journal of Geology 96, XX-XX. http://dx.doi.org/10.17850/njg96-2-06.

Smelror, M. 2015: $7^{\text {th }}$ International Conference on Arctic Margins ICAM 2015. Norges geologiske undersøkelse Report 2015.032, 143 pp

Smelror, M. \& Larssen, G.B. 2016: Are there Upper Cretaceous sedimentary rocks preserved on Sørkapp Land, Svalbard? Norwegian Journal of Geology 96, XX-XX. http://dx.doi.org/10.17850/njg962-05.

Stone, D.B., Grikurov, G.E., Clough, J.G., Oakey, G.N. \& Thurston, D.K. (eds.) 2014: ICAM VI: Proceedings of the International Conference on Arctic Margins VI, Fairbanks, Alaska, May 2011. - SPb.: Press VSEGEI, 2014, 332 pp.

Worsley, D. 2008: The post-Caledonian development of Svalbard and the western Barents Sea. Polar Research 27, 298-317. http://dx.doi. org/10.1111/j.1751-8369.2008.00085.x. 